\title{
Hydrothermal Högbomite Associated with Vanadiferous-Titaniferous (V-Ti) Bearing Magnetite Bands in Bhakatarhalli Chromite Mine, Nuggihalli Greenstone Belt, Western Dharwar Craton, Karnataka, India
}

\author{
Raju V.S. PERUMALA ${ }^{1,2}$ and Roland K.W. MERKLE ${ }^{2}$ \\ 1 National Geophysical Research Institute, PO Box 724, Hyderabad, India (Council of Scientific and \\ Industrial Research) \\ 2 Department of Geology, University of Pretoria, Pretoria, South Africa
}

\begin{abstract}
Högbomite, a rare exotic mineral, is found to be associated with the vanadiferous-titaniferous (V-Ti) bearing magnetite bands at Bhakatarhalli, Nuggihalli greenstone belt, western Dharwar Craton, India. We report on a second occurrence of högbomite from the Dharwar craton in Karnataka, which is the sixth documented occurrence of this mineral from India. We evaluate the chemical characteristics of högbomite and associated Fe-Ti-minerals in an attempt to identify its formation as a primary hydrothermal mineral in a metamorphosed magnetite layer.We report here the presence of högbomite as a complex oxide of $\mathrm{Fe}, \mathrm{Mg}, \mathrm{Al}$ and Ti with accessory of $\mathrm{Zn}, \mathrm{V}$ and $\mathrm{Sn}$. Petrographic studies suggest the (V-Ti) bearing magnetite (Mt) contain spinel, högbomite, chlorite, martite, ilmenite (II) and minor amounts of diaspore. The högbomite displays euhedral to subhedral textures, and is up to $250 \mu \mathrm{m}$ along the grain boundaries of magnetite and ilmenite. In the samples studied, högbomite is prismatic, irregular and elongated in shape. The genesis of högbomite in veins between magnetite and ilmenite implies its precipitation from fluids without involving complicated reactions. Several models were proposed for the formation of högbomite; however, the subject is still debatable.
\end{abstract}

Key words: Högbomite, western Dharwar craton, vanadium, magnetite, EPMA, India

\section{Introduction}

Högbomite is the name given to a group of minerals which are composed of variable amounts of nolanite-type $\left(\mathrm{TM}_{4} \mathrm{O}_{7}(\mathrm{OH}) ; \mathrm{T}\right.$ indicates tetrahedrally, $\mathrm{M}$ indicates octahedrally coordinated cations) and spinel $\left(\mathrm{T}_{2} \mathrm{M}_{4} \mathrm{O}_{8}\right)$ modules (Armbruster, 2002, Hejny and Armbruster 2002). Consequently, högbomite has a variety of polysomes and a widely variable composition. Högbomite is typically considered a metamorphic mineral that is assumed to have formed through a range of possible reactions involving most commonly magnetite and spinel (e.g. Petersen et al., 1988; Rakotonandrasana et al., 2010; Sengupta et al., 2009; Razakamanana et al., 2000).To date, högbomite has been reported from five localities in India: Orissa (Beura et al., 2009), Andhra Pradesh (Grew et al., 1987, 2003), Tamil Nadu (Tsunogae and Santhosh , 2005; Sengupta et al., 2009) and 2 localities in Karnataka (Devaraju et al., 1981).Here we report on a second occurrence of högbomite

\footnotetext{
* Corresponding author. E-mail: perumala.raju@gmail.com
}

from the Dharwar craton in Karnataka, which is the sixth documented occurrence of this mineral from India. We evaluate the mineral chemical characteristics of högbomite and associated Fe-Ti-minerals in an attempt to decipher the formation of högbomite as a primary hydrothermal mineral in a metamorphosed magnetite layer.

\section{Geological Setting}

The Dharwar Craton of South India is one of the major Archean crustal blocks with lithological units as old as 3.6 Ga (Ramakrishnan, 1981). It is bounded by the NarmadaSon--Godavari rift system to the north-northeast, to the west by the western margin of the subcontinent, towards the east by the Eastern Ghat mobile belt, and towards the south it is separated by granulite terrain by the transition zone (Fig. 1). The Craton was divided into the western block and the eastern block by Swaminath et al. (1976), but renamed as the Western Dharwar Craton (WDC) and the Eastern Dharwar Craton (EDC) respectively by Rogers 


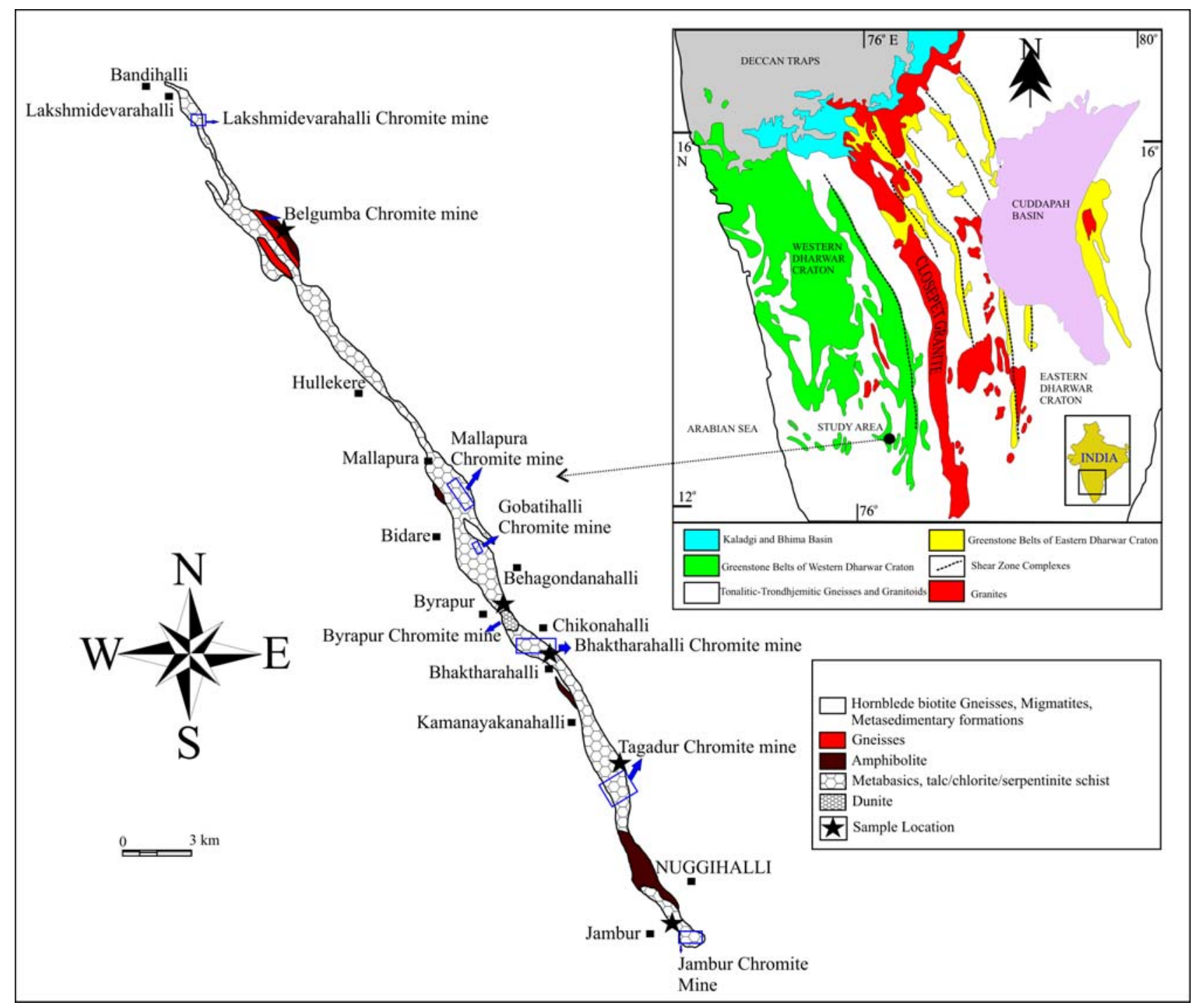

Fig. 1. Geological overview of the South India (in-set) and geological map of Nuggihalli greenstone belt.

(1986). The WDC and EDC are separated by the undefined contact with Chitradurga granite at the eastern margin of the Chitradurga schist belt near to the western margin of the Closepet granite. There are distinct changes in regional geology, lithounits and metamorphic grade between WDC and EDC, which are however, beyond the scope of this paper and have been discussed elsewhere (Raju P.V.S et al., 2011, 2009, 2006). Among the Supracrustal groups of WDC, the oldest identified Sargur Group occurs as enclaves within the gneisses, where as younger supracrustals (3 to 2.5 Ga old i.e., Late Archaean) of the Dharwar supergroup: Chitradurga,Shimoga, Bababudan and Western Ghat belts of WDC have been designated as Dharwar type schist belts by Shackelton (1976) and Goodwin (1977). The Chromite and V-Ti magnetite occur in the form of bands/layers and small lenses associated with the ultramafic-mafic complexes of the Sargur Group of the WDC. The economically exploitable chromite deposits are known in the SinduvalliTalur belt (Mysore District) and the Nuggihalli greenstone belt (Hassan district). The Nuggihalli greenstone belt extends for nearly $\sim 50 \mathrm{~km}$ (NNW trend) from Kempinkote in the South to Arsikere in the north. This belt varies from $1 \mathrm{~m}$ to $3 \mathrm{~m}$ in width, and its maximum width can be observed at the central part of the Nuggihalli. The rock type includes chromite-bearing serpentinised peridotite, talc-tremolite-chlorite schists, amphibolites metasediments (fuchsite quartzite, quartz mica chlorite schist and staurolite-quartz mica schist (Ramakrishnan, 1981). The chromitite occurs as lenses, tabular and as irregular bodies in the Nuggihalli greenstone belt. The chromitite contain chromite at mineable scale from Byrapur, Bhaktarhalli, Tagdur Ranganbetta and Jambur areas (Radhakrishna, 1957) (Fig. 1). In Nuggihalli greenstone belt V-Ti magnetite is reported throughout the belt. The $\mathrm{V}-\mathrm{Ti}$ magnetite occurs as seams/ lenses/ loads and as narrow 
bands, typically associated with pyroxenite-gabbroanorthosite litho units. The V-Ti bearing magnetite layers and lenses look in-similarity with chromite. The ultramafic bodies with chromite bearing anorthosites are deformed and mostly occur in the gneisses. So far the evidence on the age for these ultrabasic is lacking, except an estimated age of $>3.0 \mathrm{Ga}$ (Baidyananda et al., 2003). Recent work done by Mukherjee et al. (2010, 2012) on Nuggihalli greenstone belt provided a Sm-Nd measured age of (3125 $\pm 125) \mathrm{Ma}$, and suggested linkage to a stage of supercontinent amalgamation. Mukherjee et al. (2012) also discussed at length the tectno-metamorphic history and whole rock geochemical analyses of the Nuggihalli greenstone belt. These rocks constitute the Aladahalli band which forms an arm of the Nuggihalli belt extending from Byrapur to Ugrahalli, and probably are host rocks for $\mathrm{Cu}-$ Ni mineralisation (Subba Rao and Naqvi 1997).

\section{Analytical Method}

Electron Probe Micro Analysis (EPMA) of the oxide minerals of interest were carried out on polished thin sections using the fully automated Cameca SX-100 facility at the National Geophysical Research Institute, Hyderabad. Wavelength spectrometer analyses were performed using an accelerating voltage of $20 \mathrm{kV}$ and a beam current of $20 \mathrm{nA}$. The measurement time on the peak to background is $60 \mathrm{sec}$. Zinc was analyzed on LIF crystal, $\mathrm{Ni}, \mathrm{Cr}, \mathrm{V}$ and $\mathrm{Mn}$ on large LIF crystal, $\mathrm{K}, \mathrm{Ca}$ and $\mathrm{Ti}$ on large PET crystal, and $\mathrm{Al}, \mathrm{Si}$ and $\mathrm{Mg}$ on TAP crystal. The following materials were used for calibration: sphalerite for zinc, pure nickel for nickel, bustamite for manganese, chromite for chromium, $\mathrm{V}_{2} \mathrm{O}_{5}$ for vanadium, orthoclase for potassium, diopside for calcium, rutile for titanium, plagioclase for aluminum and quartz for silica). Tin was not found. Interferences between the $\mathrm{Ti}-\mathrm{K}_{\text {beta }} \mathrm{X}$-ray emission line and the $\mathrm{V}-\mathrm{K}_{\text {alpha }}$ line, as well as $\mathrm{V}-\mathrm{K}_{\text {beta }}$ and $\mathrm{Cr}-\mathrm{K}_{\text {alpha }}$ were corrected using the Cameca ${ }^{\circledR}$ overlap correction program and checked by analyzing pure element standards. Mineral standards were analyzed as unknown and re-calibrations were performed when necessary.

\section{Petrography}

The common mineral assemblage in the Fe-Ti-Mg-Alrich domains comprises spinel, and högbomite associated with diaspore, ilmenite and magnetite are accessory minerals. No obvious mineral fabrics are present in the assemblage. Chlorite and diaspore occur as secondary phases partly replacing spinel and corundum. The högbomite is pale brownish in colour and forms fine- to medium-grained (50 to $250 \mu \mathrm{m}$ ) euhedral to subhedral grains included in or scattered along grain boundaries of coarse-grained spinel aggregates and ilmenite and magnetite association. Its optical characters (weakly pleochroism, uniaxial negative, parallel extinction, high birefringence, and length slow) are all consistent with the previously reported data for högbomite. It has hexagonal morphology, when cut perpendicular to the 'c' axis (Fig. 2a), is also typical (e.g. Petersen et al., 1988). Högbomite is associated with spinel, diaspore and secondary chlorite. In this study area mostly högbomite grains contain massive Fe-oxide (magnetite-ilmenite association) (Fig.2b). The investigated samples comprise of massive magnetite with more than $80 \%$ of magnetite and ilmenite with a granoblastic texture. Magnetite and ilmenite vary in size typically from about 10 to $200 \mu \mathrm{m}$, although individual magnetite grains may approach $1 \mathrm{~mm}$ in size. The massive magnetite is intersected by vein-like features that are dominated by ilmenite and högbomite, with a smaller proportion of magnetite, and variable, but always small amounts of what we tentatively call diaspore and corundum (BSE images of Figs. 2c, d). Smooth grain boundaries and the angles between these minerals imply formation under equilibrium conditions. Some of the högbomite is rimmed and partially replaced by chlorite

\section{Analytical results}

\subsection{Mineral chemistry}

\subsubsection{Magnetite in matrix and veins}

Twenty-three analyses by EPMA (magnetite in the matrix and in vein) (Table 1) shows that there is very few difference in composition of the magnetite in the two textural settings. The compositional ranges overlap widely, but it appears that the magnetite in the veins has slightly higher concentrations of $\mathrm{Ti}$ and $\mathrm{Cr}$, while the matrix magnetite has higher vanadium contents.

\subsubsection{Ilmenite in matrix and veins}

Several differences can be observed between the analyses of ilmenite in the matrix and the veins (Table 2) . Vein ilmenite is higher in titanium and some of the grains appear to have slightly higher $\mathrm{Zn}$ contents than the matrix ilmenite, while some of the matrix ilmenite has higher $\mathrm{Mg}$ and vanadium contents. Ilmenite contains on average less than $1 \mathrm{wt} \%$ of $\mathrm{MgO}$, but there are some $\mathrm{Mg}$-enriched ilmenite grains which formed as exsolutions from very large magnetite grains in the magnetitite. Some analyses of ilmenite from the matrix demonstrate vanadium contents around $1 \mathrm{wt} \%$ which is substantially higher than observed for the vein ilmenite, while others show concentrations overlapping with vein ilmenites. No particular reason or characteristics for the $\mathrm{Zn}$-enriched or 

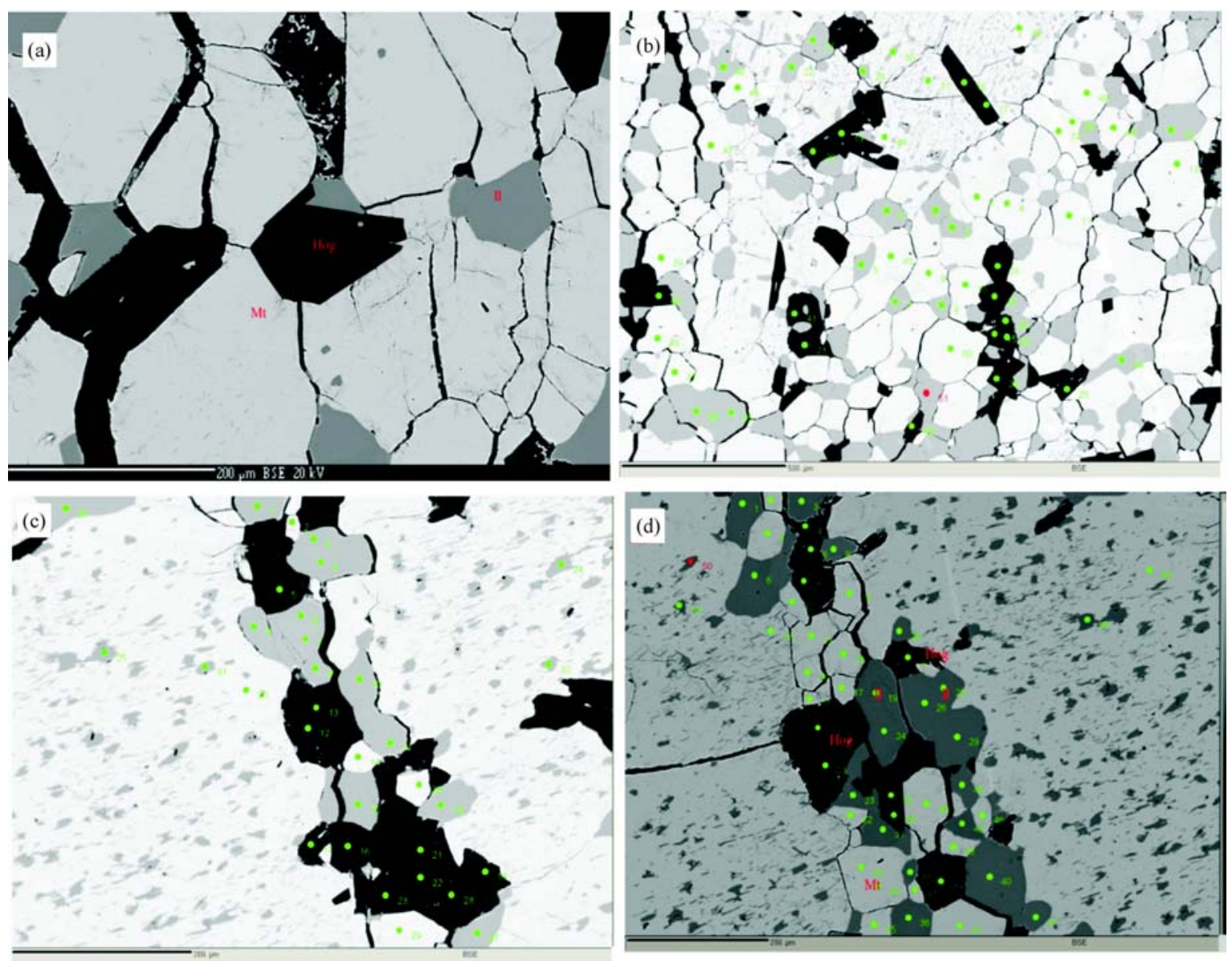

Fig. 2. (a), BSE image of högbomite (hexagonal) associated with ilmenite and magnetite; (b), Högbomite associated with ilmenite and magnetite (the exsolutions of ilmenite are in middle). The green dots indicate the spot analyses; (c), Hogbomite with association of ilmenite-magnetite in vein form; (d), Högbomite associated with ilmenite-magnetite as a thin the matrix show exsolution lamellae.

Table 1 Summary of compositional variation of magnetite

\begin{tabular}{llllll}
\hline Mineral & $\mathrm{N}$ & Minimum & Maximum & Mean & Std.Dev. \\
\hline Magnetite vein & & & & & \\
\hline $\mathrm{TiO}_{2}$ & 23 & 0.11 & 2.29 & 0.58 & 0.48 \\
$\mathrm{Al}_{2} \mathrm{O}_{3}$ & 23 & 0.11 & 0.47 & 0.27 & 0.09 \\
$\mathrm{MgO}$ & 23 & 0.02 & 0.17 & 0.07 & 0.04 \\
$\mathrm{Cr}_{2} \mathrm{O}_{3}$ & 23 & 1.53 & 1.89 & 1.68 & 0.08 \\
$\mathrm{MnO}$ & 23 & 0 & 0.06 & 0.01 & 0.02 \\
$\mathrm{FeO}$ & 23 & 87.23 & 89.71 & 88.51 & 0.75 \\
$\mathrm{NiO}$ & 23 & 0 & 0.25 & 0.11 & 0.05 \\
$\mathrm{~V}_{2} \mathrm{O}_{3}$ & 23 & 0.93 & 1.11 & 1.04 & 0.05 \\
$\mathrm{ZnO}^{\mathrm{Magnetite} \mathrm{matrix}}$ & 23 & 0 & 0.12 & 0.04 & 0.04 \\
\hline $\mathrm{TiO}_{2}$ & 23 & 0.04 & 1.47 & 0.26 & 0.34 \\
$\mathrm{Al}_{2} \mathrm{O}_{3}$ & 23 & 0.16 & 0.77 & 0.34 & 0.16 \\
$\mathrm{MgO}_{\mathrm{Cr}} \mathrm{O}_{3}$ & 23 & 0.03 & 0.23 & 0.10 & 0.05 \\
$\mathrm{MnO}$ & 23 & 0.57 & 1.77 & 1.54 & 0.23 \\
$\mathrm{FeO}$ & 23 & 0 & 0.03 & 0.00 & 0.01 \\
$\mathrm{NiO}$ & 23 & 85.82 & 89.31 & 87.42 & 0.77 \\
$\mathrm{ZnO}_{2}$ & 23 & 0.01 & 0.16 & 0.10 & 0.04 \\
$\mathrm{ZnO}^{\mathrm{Uni}}$ & 23 & 1.01 & 1.18 & 1.12 & 0.04 \\
& 23 & 0 & 0.14 & 0.03 & 0.04
\end{tabular}

Unit for oxide is $w t \%$.
Table 2 Summary of compositional variation of ilmenite

\begin{tabular}{|c|c|c|c|c|c|}
\hline Mineral & $\mathrm{N}$ & Minimum & Maximum & Mean & Std.Dev. \\
\hline \multicolumn{6}{|c|}{ Ilmenite vein } \\
\hline$\overline{\mathrm{TiO}_{2}}$ & 28 & 52.60 & 55.14 & 53.64 & 0.59 \\
\hline $\mathrm{Al}_{2} \mathrm{O}_{3}$ & 28 & 0.00 & 0.05 & 0.00 & 0.01 \\
\hline $\mathrm{MgO}$ & 28 & 0.55 & 0.91 & 0.71 & 0.10 \\
\hline $\mathrm{Cr}_{2} \mathrm{O}_{3}$ & 28 & 0.04 & 0.27 & 0.10 & 0.05 \\
\hline $\mathrm{MnO}$ & 28 & 0.91 & 1.15 & 1.06 & 0.07 \\
\hline $\mathrm{FeO}$ & 28 & 43.78 & 46.76 & 45.45 & 0.70 \\
\hline $\mathrm{NiO}$ & 28 & 0.00 & 0.11 & 0.03 & 0.03 \\
\hline $\mathrm{V}_{2} \mathrm{O}_{3}$ & 28 & 0.25 & 0.60 & 0.41 & 0.09 \\
\hline $\mathrm{ZnO}$ & 28 & 0.00 & 1.35 & 0.25 & 0.25 \\
\hline \multicolumn{6}{|c|}{ Ilmenite matrix } \\
\hline$\overline{\mathrm{TiO}_{2}}$ & 22 & 50.87 & 54.25 & 51.84 & 0.85 \\
\hline $\mathrm{Al}_{2} \mathrm{O}_{3}$ & 22 & 0.00 & 0.00 & 0.00 & 0.00 \\
\hline $\mathrm{MgO}$ & 22 & 0.58 & 1.68 & 0.94 & 0.32 \\
\hline $\mathrm{Cr}_{2} \mathrm{O}_{3}$ & 22 & 0.02 & 0.22 & 0.10 & 0.05 \\
\hline $\mathrm{MnO}$ & 22 & 0.93 & 1.24 & 1.07 & 0.08 \\
\hline $\mathrm{FeO}$ & 22 & 44.20 & 46.63 & 45.28 & 0.52 \\
\hline $\mathrm{NiO}$ & 22 & 0.00 & 0.08 & 0.02 & 0.02 \\
\hline $\mathrm{V}_{2} \mathrm{O}_{3}$ & 22 & 0.28 & 1.11 & 0.81 & 0.30 \\
\hline $\mathrm{ZnO}$ & 22 & 0.00 & 0.26 & 0.09 & 0.08 \\
\hline
\end{tabular}

Unit for oxide is $w t \%$. 
V-enriched ilmenite could be identified. There seems to be a systematic negative relationship between Ti and V (Fig. 3a), but no systematic relationship between $\mathrm{Cr}$ and $\mathrm{V}$.

\subsubsection{Högbomite in matrix and veins}

The small number of analyses makes a statistical evaluation difficult, but there is an indication that there may be a negative relationship between $\mathrm{Ti}$ and $\mathrm{Al}$ or $\mathrm{Zn}$
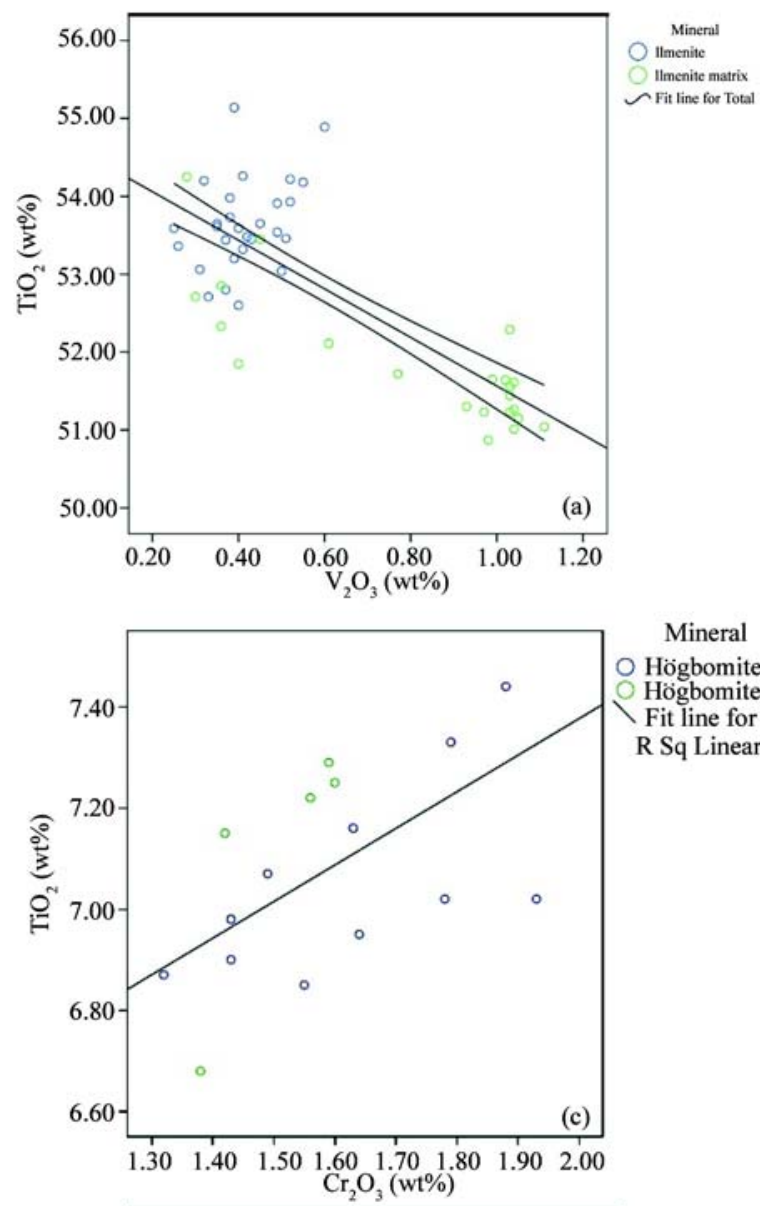

Mineral

Högbomite Högbomite matrix Fit line for Total

$\mathrm{R}$ Sq Linear $=0.40$
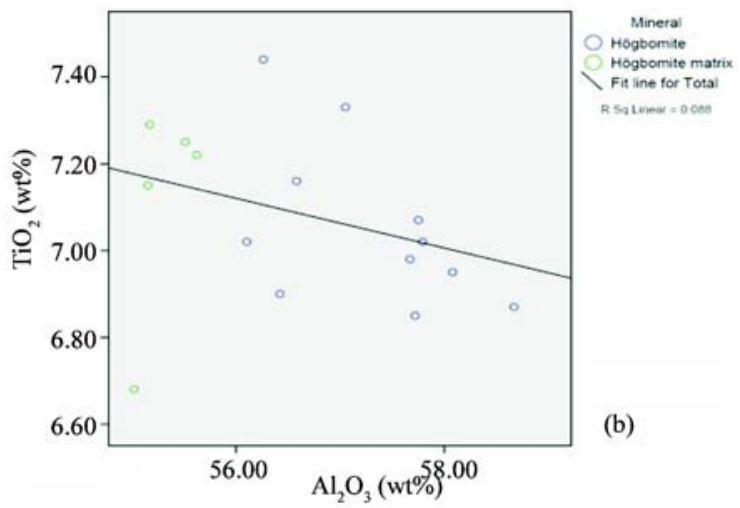

(Fig. 3b), a negative relationship between $\mathrm{Al}$ and $\mathrm{V}$, but a positive relationship between $\mathrm{Ti}$ and $\mathrm{Cr}$ or total $\mathrm{Fe}$ (Fig. $3 c$ ). If any difference in composition exists at all, vanadium seems to be the most likely candidate, with vanadium in the vein-hogbomite being slightly lower than in the matrix (Table 3) .

\subsubsection{Others (corundum, diaspore)}

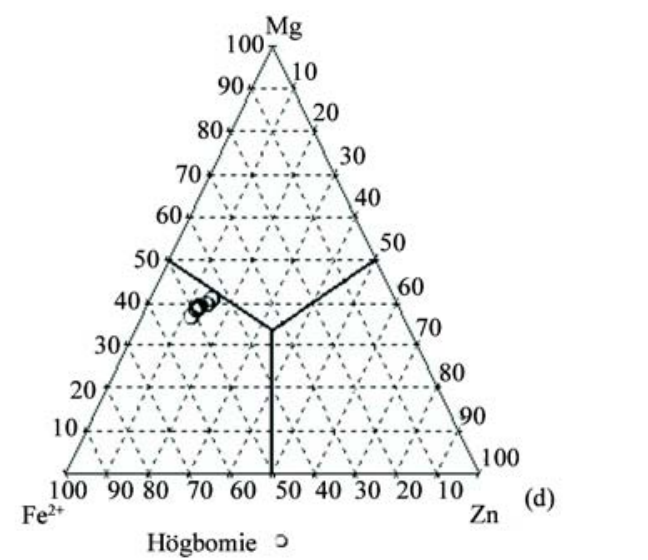

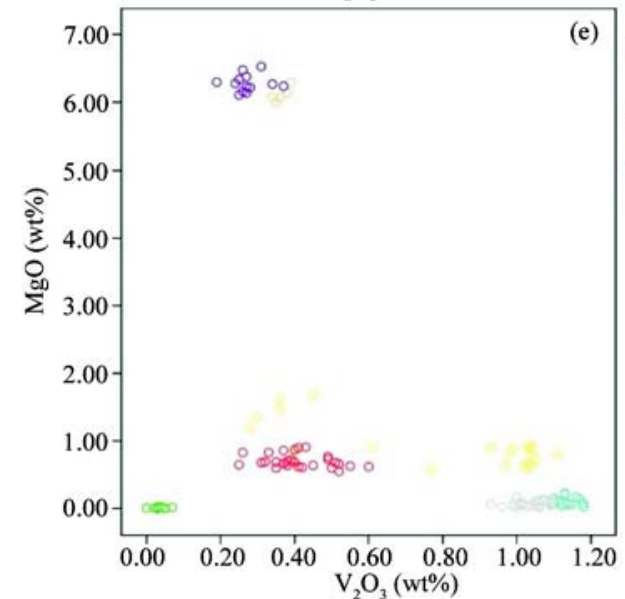
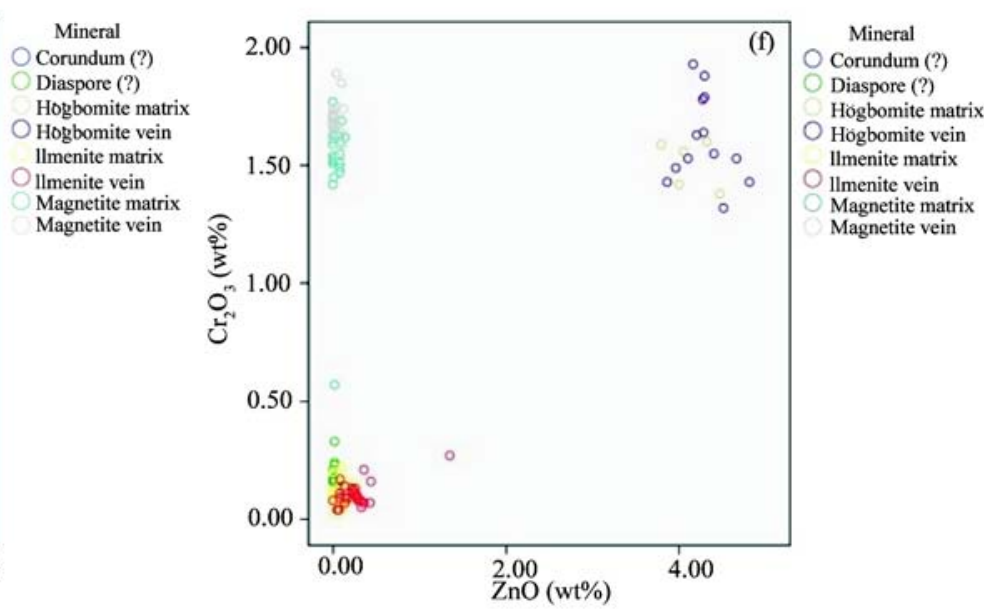

Fig. 3. (a), Binary diagram of $\mathrm{TiO}_{2} \mathrm{vs}_{2} \mathrm{O}_{3}$ in ilmenite and ilmenite matrix; (b), Binary diagram of $\mathrm{TiO}_{2}$ vs $\mathrm{Al}_{2} \mathrm{O}_{3}$ in högbomite; (c), Binary diagram of $\mathrm{TiO}_{2} \mathrm{vs} \mathrm{Cr}_{2} \mathrm{O}_{3}$ in högbomite; (d), Ternary plot of $\mathrm{Fe}-\mathrm{Mg}-\mathrm{Zn}$ in Cation \% and högbomite present in ferro-högbomite; (e), Binary diagram of $\mathrm{MgO}$ vs $\mathrm{V}_{2} \mathrm{O}_{3}$ in magnetite, magnetite matrix, ilmenite vein and matrix, hogbomite vein and matrix, corundum and diaspore; (f), Binary diagram of $\mathrm{Cr}_{2} \mathrm{O}_{3}$ vs $\mathrm{ZnO}$ in högbomite and magnetite. 
Some analyses of mineral grains in the veins and matrix gave compositions around $84 \mathrm{wt} \% \mathrm{Al}_{2} \mathrm{O}_{3}$ (Table 4) with minor titanium, chromium and iron, which agrees well with the theoretical composition of $\mathrm{AlO}(\mathrm{OH})$ of 84.98 wt $\% \mathrm{Al}_{2} \mathrm{O}_{3}$. We have not confirmed the exact nature of this mineral and therefore call it tentatively diaspore (?). One grain, consisting of diaspore and corundum produced a composition for corundum of almost pure $\mathrm{Al}_{2} \mathrm{O}_{3}$ with $0.13 \mathrm{wt} \% \mathrm{Cr}_{2} \mathrm{O}_{3}$ and $0.77 \mathrm{wt} \% \mathrm{Fe}_{2} \mathrm{O}_{3}$.

\section{Discussions}

Comparing the analyzed minerals in the veins and matrix, and looking at "non-essential" elements for magnetite and ilmenite $(\mathrm{Cr}, \mathrm{V}, \mathrm{Zn}, \mathrm{Mg})$, we get an indication where these non-essential elements like to partition into if titaniferous magnetite, ilmenite, and högbomite coexist.

Despite the Fe-rich environment and the possibility to incorporate both iron and magnesium into the högbomite structure, högbomite is the mineral with the highest magnesium enrichment. However, following the guidelines of Armbruster (2002), Fe is the dominant 2+ cation (calculated to achieve charge balance; (Fig. 3d (ternary plot of Fe-Mg-Zn) in cat-\%) and the högbomite encountered in this study is in all likelihood ferrohögbomite.

Chromium is concentrated in högbomite and magnetite to similar concentration levels, but the concentrations of vanadium in högbomite are relatively low, much lower

Table 3 Summary of compositional variation of högbomite

\begin{tabular}{|c|c|c|c|c|c|}
\hline Mineral & $\mathrm{N}$ & Minimum & Maximum & Mean & Std.Dev. \\
\hline \multicolumn{6}{|c|}{ Högbomite veins } \\
\hline $\mathrm{TiO}_{2}$ & 13 & 6.85 & 7.44 & 7.07 & 0.21 \\
\hline $\mathrm{Al}_{2} \mathrm{O}_{3}$ & 13 & 56.10 & 58.67 & 57.14 & 0.85 \\
\hline $\mathrm{MgO}$ & 13 & 6.11 & 6.53 & 6.31 & 0.14 \\
\hline $\mathrm{Cr}_{2} \mathrm{O}_{3}$ & 13 & 1.32 & 1.93 & 1.63 & 0.21 \\
\hline $\mathrm{MnO}$ & 13 & 0.07 & 0.17 & 0.12 & 0.03 \\
\hline $\mathrm{FeO}$ & 13 & 20.34 & 22.05 & 21.32 & 0.59 \\
\hline $\mathrm{NiO}$ & 13 & 0.15 & 0.32 & 0.23 & 0.04 \\
\hline $\mathrm{V}_{2} \mathrm{O}_{3}$ & 13 & 0.19 & 0.34 & 0.27 & 0.04 \\
\hline $\mathrm{ZnO}$ & 13 & 3.86 & 4.81 & 4.32 & 0.28 \\
\hline \multicolumn{6}{|c|}{ Högbomite matrix } \\
\hline $\mathrm{TiO}_{2}$ & 5 & 6.68 & 7.29 & 7.12 & 0.25 \\
\hline $\mathrm{Al}_{2} \mathrm{O}_{3}$ & 5 & 55.02 & 55.62 & 55.29 & 0.26 \\
\hline $\mathrm{MgO}$ & 5 & 6.00 & 6.30 & 6.12 & 0.11 \\
\hline $\mathrm{Cr}_{2} \mathrm{O}_{3}$ & 5 & 1.38 & 1.60 & 1.51 & 0.10 \\
\hline $\mathrm{MnO}$ & 5 & 0.06 & 0.19 & 0.12 & 0.06 \\
\hline $\mathrm{FeO}$ & 5 & 19.82 & 21.40 & 20.92 & 0.63 \\
\hline $\mathrm{NiO}$ & 5 & 0.18 & 0.31 & 0.24 & 0.05 \\
\hline $\mathrm{V}_{2} \mathrm{O}_{3}$ & 5 & 0.34 & 0.39 & 0.36 & 0.02 \\
\hline $\mathrm{ZnO}$ & 5 & 3.79 & 4.47 & 4.13 & 0.27 \\
\hline
\end{tabular}

Table 4 Summary of compositional variation of diaspore

\begin{tabular}{cccccc}
\hline & $\mathrm{N}$ & Minimum & Maximum & Mean & Std. Dev. \\
\hline $\mathrm{TiO}_{2}$ & 8 & 0.02 & 0.22 & 0.10 & 0.07 \\
$\mathrm{Al}_{2} \mathrm{O}_{3}$ & 8 & 83.51 & 85.22 & 84.38 & 0.70 \\
$\mathrm{Cr}_{2} \mathrm{O}_{3}$ & 8 & 0.16 & 0.33 & 0.21 & 0.06 \\
$\mathrm{FeO}$ & 8 & 0.51 & 0.98 & 0.68 & 0.16 \\
$\mathrm{~V}_{2} \mathrm{O}_{3}$ & 8 & 0.00 & 0.07 & 0.04 & 0.02 \\
\hline
\end{tabular}

Unit for oxide is $w t \%$. than for magnetite and some of the ilmenite grains (Fig.4e; $(\mathrm{Mg}-\mathrm{V})$. It is noteworthy that both the magnetite and the högbomite in the veins have slightly lower vanadium contents than the grains in the matrix.

Ilmenite in veins and matrix contains minor concentrations of $\mathrm{Zn}$ with a tendency for slightly higher amounts in ilmenite in the veins. However, in the ilmenitemagnetite- högbomite assemblage, zinc is strongly concentrated in högbomite (Table $5 \mathrm{Kd}$ values; Fig 3f ; Cr$\mathrm{Zn})$.

Table 5 is a summary of partition coefficients (wt-\% oxide), based on averages and extreme values in the vein assemblage only (in the matrix, $\mathrm{MgO}$ and $\mathrm{V}_{2} \mathrm{O}_{3}$ in ilmenite vary widely, implying a whole range of processes we do not understand and can not quantify). By using only the vein, we have 1 set of data that seems to represent 1 event and 1 process. ${ }^{*}$ means the value can not be calculated because the lowest values are below the detection limit.

\subsection{Högbomite composition}

A högbomite sample has distinctly high $\mathrm{Ti}$ and $\mathrm{Fe}$ content and low $\mathrm{Al}$ content, implying the interference of ilmenite in this analysis. However, there is no textural evidence for the interference, and the analysis was therefore not excluded. Compared to the literature data, the högbomite in this study is high in Ti and low Al (Fig. $4 \mathrm{a}$; (Ti-Al), about average in $\mathrm{MgO}$ and $\mathrm{ZnO}$, low in $\mathrm{MnO}$ (Fig. 4b; (Mn-Zn), and unusually high in $\mathrm{V}$ and $\mathrm{Cr}$ (Fig. 4c; (V-Cr). The latter could be because the fluids were at least in partial equilibrium with the matrix magnetitite, which in itself is high in $\mathrm{Cr}$ and $\mathrm{V}$ compared to most of the environments in which högbomite has been described. The $\mathrm{Mg}$ content of the högbomite is towards the lower end of the range compared to literature data. Again this can be attributed to the low $\mathrm{Mg}$ content of the matrix and consequently the fluid.

The formation of högbomite exclusively or predominantly through metamorphic reactions requires the

Table 5 Summary of partition coefficients (wt \% oxide)

\begin{tabular}{lllll}
\hline & & average & extreme 1 & extreme 2 \\
\hline $\mathrm{MgO}$ & $\mathrm{Kd} \mathrm{Hög} / \mathrm{Ilm}$ & 8.90 & 11.87 & 6.71 \\
& $\mathrm{Kd} \mathrm{Hög} / \mathrm{Mt}$ & 94.48 & 326.50 & 35.94 \\
& $\mathrm{Kd} \mathrm{Ilm} / \mathrm{Mt}$ & 10.61 & 45.50 & 3.24 \\
$\mathrm{Cr}_{2} \mathrm{O}_{3}$ & $\mathrm{Kd} \mathrm{Hög} / \mathrm{Ilm}$ & 15.44 & 7.15 & 4.89 \\
& $\mathrm{Kd} \mathrm{Hög} / \mathrm{Mt}$ & 0.96 & 1.02 & 0.70 \\
& $\mathrm{Kd} \mathrm{Ilm} / \mathrm{Mt}$ & 0.06 & 0.14 & 0.02 \\
$\mathrm{MnO}$ & $\mathrm{Kd} \mathrm{Hög} / \mathrm{Ilm}$ & 0.12 & 0.22 & 0.06 \\
& $\mathrm{Kd} \mathrm{Hög} / \mathrm{Mt}$ & 14.77 & $*$ & 1.17 \\
& $\mathrm{Kd} \mathrm{Ilm} / \mathrm{Mt}$ & 121.60 & $*$ & 15.17 \\
$\mathrm{~V}_{2} \mathrm{O}_{3}$ & $\mathrm{Kd} \mathrm{Hög} / \mathrm{Ilm}$ & 0.66 & 1.48 & 0.32 \\
& $\mathrm{Kd} \mathrm{Hög} / \mathrm{Mt}$ & 0.26 & 0.40 & 0.17 \\
& $\mathrm{Kd} \mathrm{Ilm} / \mathrm{Mt}$ & 0.40 & 0.65 & 0.23 \\
$\mathrm{ZnO}$ & $\mathrm{Kd} \mathrm{Hög} / \mathrm{Ilm}$ & 17.29 & $*$ & 2.86 \\
& $\mathrm{Kd} \mathrm{Hög} / \mathrm{Mt}$ & 112.05 & $*$ & 32.17 \\
& $\mathrm{Kd} \mathrm{Ilm} / \mathrm{Mt}$ & 6.48 & $*$ & $*$ \\
\hline
\end{tabular}



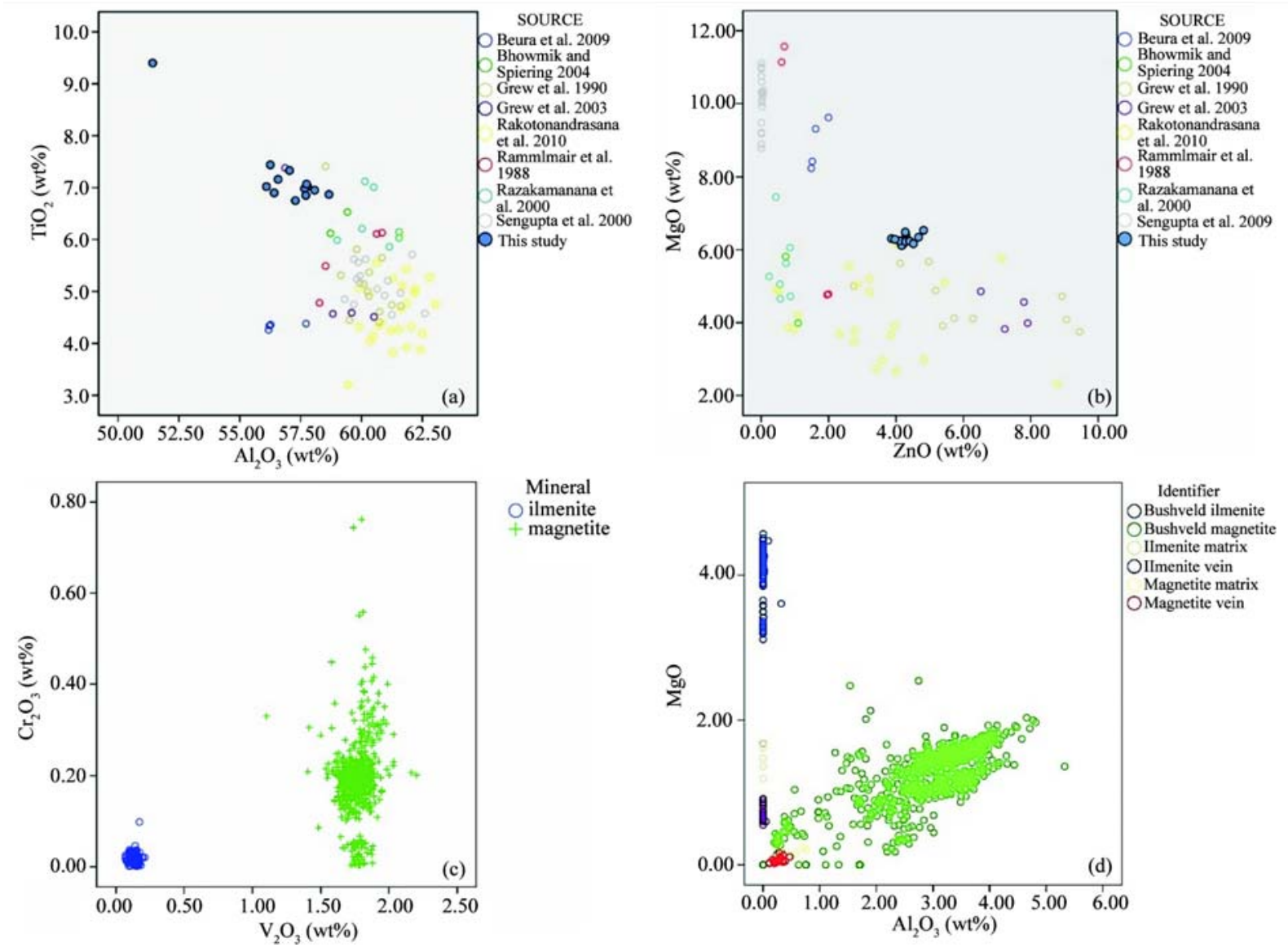

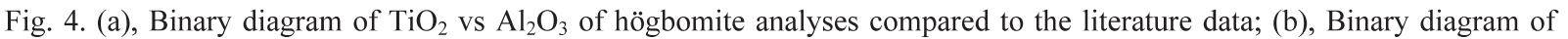
$\mathrm{ZnO}$ vs $\mathrm{MgO}$ of högbomite analyses in comparision to the literature data; (c), Binary diagram of $\mathrm{Cr}$ vs V in ilmenite and magnetite data from magnetite layer of Bushveld complex; (d), Binary diagram of $\mathrm{Mg}$ vs $\mathrm{Al}$ the ilmenite and magnetite data from Bushveld complex.

availability of $\mathrm{Al}$ (and also of $\mathrm{Mg}$ ). Our magnetitite does not contain an obvious source of Al. It is inferred that the concentration of $\mathrm{Al}$ in magnetite obviously depends on the intrinsic conditions in the melt during crystallization (i.e., whether the silicate melt was saturated in plagioclase component at the time of magnetite formation or not). Comparison of the Bushveld data (Fig. 5d) with the data in this study shows that the Bushveld magnetite (with an average $\mathrm{Al}_{2} \mathrm{O}_{3}$ content of close to $3 \mathrm{wt} \%$ and a maximum of $5.3 \mathrm{wt} \%$; average $\mathrm{MgO}$ content of $1.2 \mathrm{wt} \%$ and up to $2.5 \mathrm{wt} \%$ ) in solid solution after exsolution of $\mathrm{Al}-$ and $\mathrm{Mg}$ containing phases (Butcher and Merkle 1987) appears still higher than in our data set with less than $0.5 \mathrm{wt} \%$ and 0.07 wt $\%$ respectively. This affords the possibility that the magnetite could have expelled substantial amounts of Al and $\mathrm{Mg}$, which could have contributed to the högbomite formation. Textural considerations imply that the högbomite in this study did not form by any of the commonly proposed metamorphic reactions (e.g. Petersen et al., 1988; Rakotonandrasana et al., 2010; Sengupta et al., 2009; Razakamanana et al., 2000). Because the composition of metamorphic fluids and the minerals they interact with are too complex to exclude any combination of processes, any element not present in the pre-reaction minerals can always be assumed to be provided by the fluids. However, in an environment like a meta-igneous magnetitite, $\mathrm{Zn}$ in any of the primary minerals present will be extremely low. Would högbomite form through a purely metamorphic reaction in such an environment, $\mathrm{Zn}$ contents in högbomite should be very low. The analyses reported by Sengupta et al. (2009) from the Sittampundi Complex agree well with this argument. The substantial amount of $\mathrm{Zn}$ in our högbomite therefore requires an external source for the $\mathrm{Zn}$, and consequently of the fluid itself. That the vein ilmenite has a tendency towards higher $\mathrm{Zn}$ than the matrix ilmenite is consistent with such an interpretation.

\subsection{Vanadium in ilmenite}

The graphical presentation (Fig. 4d) of 813 electron microprobe analyses of ilmenite and magnetite from the Main Magnetite Layer of the Bushveld Complex, South 
Africa. We use 813 analyses as being representative of the distribution of vanadium and chromium between magnetite and ilmenite in magmatic bodies. Although the absolute values vary as a function of silicate melt composition, temperature, and oxygen fugacity, magnetite tends to be enriched in chromium and vanadium relative to coexisting ilmenite (e.g., Tugarinov et al., 1975; Schuiling and Feenstra, 1980, Grammatikopoulos et al. 2002).

As described, ilmenite exsolutions in large magnetite grains in the matrix differ from this expected scheme by being clearly enriched in vanadium $(\mathrm{Cr}-\mathrm{V})$ of $(\mathrm{ilm}+\mathrm{mt})$, while other ilmenite grains show lower vanadium contents, at concentration as would be expected. We took utmost care to ensure that no analytical artifact is responsible for this anomaly and could reproduce these elevated vanadium contents.

We were able to find two references to a comparable situation (Schuiling and Feenstra, 1980; Beura et al., 2009), but in neither case are the information on the analytical technique detailed enough to exclude an analytical artifact (e.g., insufficient peak overlap correction). Schuiling and Feenstra (1980) performed experiments and achieved preferred partitioning of vanadium into ilmenite under highly oxidizing conditions (close to the magnetite-hematite buffer). This affords the possibility that partitioning of vanadium into ilmenite instead into magnetite could occur in nature as well.

Although the exact average oxidation state of vanadium in mafic melts varies, an average oxidation state approaching 4+ appears to be normal in terrestrial melts (Papike et al., 2004, 2005), which facilitates partitioning of vanadium preferentially into magnetite. Canil (2002) suggested that vanadium partitioned more strongly into a spinel structure at lower oxygen fugacities and hence lower average oxidation state, but it is known that this is not the only controlling factor (Righter et al., 2006). It appears that only at oxygen fugacities higher than normally encountered in silicate melts (close to the magnetite-hematite buffer) vanadium partitions preferentially into ilmenite (Schuiling and Feenstra, 1980). Although a scenario could be constructed in which secondary oxidation of a magmatic vanadiferous assemblage of ilmenite and magnetite may create the conditions conducive for incorporation of vanadium into ilmenite, it is difficult to argue that such a distribution would survive regional metamorphism in which magnetite and ilmenite re-form and vanadium partitions into ilmenite exsolutions from the magnetite on cooling.

We have not determined the oxidation state of vanadium in a system or rock where vanadium preferentially partitions into ilmenite and therefore refrain from any speculation about the incorporation of vanadium into the ilmenite structure.

\section{Conclusions}

(1) The Cr-V and inverse relationship between magnetite and ilmenite in the matrix implies very oxidizing localized conditions during metamorphism (and equilibration between magnetite and ilmenite), but less oxidizing conditions during the formation of the veins (implying a different event).

(2) Textures imply equilibrium precipitation from fluids.

(3) The occurrence in veins and the composition of högbomite implies precipitation from fluids without involving complicated reactions.

(4) This is the second report on the occurrence of högbomite from Dharwar Craton and also the sixth such Occurrence from India.

(5) Typically the högbomite group minerals are present along the grain boundaries of ilmenite and magnetite.

(6) This study may help use högbomite-bearing assemblages to understand the evolutionary history of ancient orogenic or hydrothermal systems.

\section{Acknowledgements}

Funding by the DST and SHORE (CSIR) are gratefully acknowledged. We would like to thank Prof Mrinal K, Sen for his kind support and encouragement to this study, and Dr Babu for the EPMA facility. The reviewers are thanked for their sage advice which improved the quality of the manuscript.

\section{References}

Armbruster, T., 2002. Revised nomenclature of högbomite, nigerite, and taaffeite minerals. European Journal of Mineralogy, 14: 389-395.

Baidyananda, M., Deomurari, M.P., and Goswami, J.N., 2003. ${ }^{207} \mathrm{~Pb}-{ }^{206} \mathrm{~Pb}$ ages of zircon from Nuggihalli schist belt, Dharwar Craton, Southern India. Current Science, 85: 14821485.

Beura, D., Acharya, D., Singh, P., and Acharya, S., 2009. Högbomite associated with vanadium bearing titaniferous magnetite of mafic-ultramafic suite of Moulabhanj Igneous Complex, Orissa, India. Journal of Minerals and Minerals Characterization and Engineering, 8(9): 745-753.

Butcher, A.R., and Merkle, R.K.W., 1987. Postcumulus modification of magnetite grains in the upper zone of the Bushveld Complex, South Africa. Lithos, 20: 247-260.

Canil, D., 2002. Vanadium in peridotites, mantle redox state and tectonic environments: Archean to present. Earth and 
Planetary Science Letters, 195: 75-90.

Devaraju, T.C., Uttangi, V.H., and Coolen, J.J.M., 1981. Högbomite from Fe-Ti deposits of Madangere, Ankola Taluk, Karnataka. Journal of the Geological Society of India, 22: 439-443.

Grammatikopoulos, T., MCKen, A., Hamilton, C., and Christiansen, O., 2002. A vanadium-bearing magnetite and ilmenite mineralization and beneficiation from the Sinarsuk V-Ti project, West Greenland. CIM bulletin, 95(1060): 87-95.

Grew, E.S., Abraham, K., and Medenbach, O., 1987. Ti-poor högbomite in kornerupine- cordierite-sillimanite rocks from Ellammankovilpatti, Tamil Nadu, India. Contributions to Mineralogy and Petrology, 95: 21-31.

Grew, E.S., Rao, A.T., Raju, K.K.V.S., Hejny, C., Moore, J.M., Waters, D.J., Yates, M.G., and Shearer, C.K., 2003. Prismatine and ferrohögbomite-2N2S in granulite-facies Feoxide lenses in the Eastern Ghats Belt at Venugopalapuram, Vizianagaram district, Andhra Pradesh, India: do such lenses have a tourmaline-enriched lateritic precursor? Mineralogical Magazine , 67: 1081-1098.

Goodwin, A.M., 1977. Archaean basin-craton complexes and the growth of Precambrian shields. Canadian Journal of . Earth Sciences., 14: 2737-2759.

Hejny, C., and Armbruster, T., 2002. Polysomatism in högbomite: The crystal structures of $10 T, 12 \mathrm{H}, 14 \mathrm{~T}$ and $24 \mathrm{R}$ polysomes. American Mineralogist, 28: 277-292.

Mukherjee, R., Mondal, Sisir K., Frei Robert, Rosing Minik T., Waight Tod E., Zhong Hong and Ravindra Kumar G.R., 2012. The $3.1 \mathrm{Ga}$ Nuggihalli chromite deposits, Western Dharwar craton (India): Geochemical and isotopic constraints on mantle sources, crustal evolution and implications for supercontinent formation and ore mineralization. Lithos, 155: 392-409.

Mukherjee, R., Mondal, S.K., Rosing, M.T., and Frei, R., 2010. Compositional variations in the Mesoarchean chromites of the Nuggihalli schist belt, Western Dharwar craton (India): potential parental melts and implications for tectonic setting. Contributions to Mineralogy and Petrology, 160: 865-885.

Rakotonandrasana, N.O.T., Arima, M., Miyawaki, R., and Rambeloson, R.A., 2010. Widespread occurrences of Högbomite-2N2S in UHT metapelites from the Betroka Belt, Southern Madagascar: Implications on melt or fluid activity during regional metamorphism. Journal of Petrology, 51(4): 869-895.

Papike, J.J., Karner, J.M., and Shearer, C.K., 2004. Comparative planetary mineralogy: $\mathrm{V} /(\mathrm{Cr}+\mathrm{Al})$ systematics in chromite as an indicator of relative oxygen fugacity. American Mineralogist, 89: 1557-1560.

Papike, J.J., Karner, J.M., and Shearer, C.K., 2005. Comparative planetary mineralogy: Valence state partitioning of $\mathrm{Cr}, \mathrm{Fe}$, Ti, and $\mathrm{V}$ among crystallographic sites in olivine, pyroxene, and spinel from planetary basalts. American Mineralogist, 90: 277-290

Petersen, L.U., Essene, E.J., Peacor, D.R., and Marcouy, L.A., 1988. The occurrence of högbomite in high-grade metamorphic rocks. Contributions to Mineralogy and Petrology, 101: 350-360.

Radhakrishna, B.P., 1957. The mode of occurrence of chromite at Byrapur, Mysore state, India. Bulletin Mysore Geological Association, 16: 1-24.

Raju, P.V.S., 2009. Petrography and geochemical behaviour of trace element, REE and precious metal signatures in sulphidic banded iron formation of C.S.Halli, Chitradurga Schist Belt,
Dharwar Craton, Journal of Asian Earth Sciences, 34: 663673.

Raju, P.V.S., Charan, S.N., Subba Rao, D.V., Uday Raj, B., and Naqvi, S.M., 2006. Nature of shear zone hosted epigenetic gold mineralisation in BIF of Chitradurga Schist Belt, Karnataka, Journal of the Geological Society of India, 68: 577-581.

Raju, P.V.S., Babu EVSSK and Merkle, R.K.W., 2011. New Data on the mineralogy of chromite from the Nuggihalli Shist belt, Western Dharwar Craton,Karnataka, India: Petrogentic Implications. Acta Geologica Sinica (English Edition), 85(1): 107-115.

Ramakrishnan, M., 1981. Nuggihalli and Krishnarajpet belts, EarlyPrecambrian supracrustals of southern Karnataka: India edn, Early Precambrian Supracrustals of Southern Karnataka, Geol. Surv. India Memo. 112: 249-259.

Razakamanana, T., Ackermand, D., and Windley, B.F., 2000. Högbomite in migmatitic paragneiss in the Betroka shear belt, Vohidava area, Precambrian of southern Madagascar. Mineralogy and Petrology, 68: 257-269.

Righter K., Leeman W.P., and Hervig, R.L., 2006. Partitioning of $\mathrm{Ni}, \mathrm{Co}$ and $\mathrm{V}$ between spinel-structured oxides and silicate melts: Importance of spinel composition. Chemical Geology, 227: $1-25$.

Rogers, J.J.W., 1986. Dharwar Craton and the assembly of Peninsular India. Journal of Geology, 94: 129-143.

Schulling, R.D., and Feenstra, A., 1980. Geochemical behaviour of vanadium in iron-titanium oxides. Chemical Geology, 30: $143-150$.

Sengupta, P., Uttam, K.B., Braun, I., Dutta, U., and Mukhopadhyay, D., 2009. Chemical substitutionns, paragentic relation and physical conditions of formation of högbomite in the Sittampundi layered Anorthosite Compelx, South India. American Mineralogist, 94: 1520-1534.

Shakelton, R.M., 1976. Shallow and deep level exposures of Archaean crust in India and Africa. In: Windley, B.F. (ed.), The Early History of the Earth. Wiley, London, 317-321.

Subba Rao, D.V., and Naqvi, S.M., 1997. Geological setting, mineralogy, geochemistry and genesis of the Middle Archaean Kalyadi copper deposit, western Dharwar craton, southern India. Mineralium Deposita, 32: 230-242.

Swaminath, J., Ramakrishnan, M., and Viswanatha, M.N., 1976. Dharwar stratigraphic model and Karnataka craton evolution. Record Geological Survey of India, 107(1): 149-175.

Tsunogae, T., and Santosh, M., 2005. Ti-free högbomite in spinel- and sapphirine-bearing $\mathrm{Mg}-\mathrm{Al}$ rock from the PalghatCauvery shear zone system, southern India. Mineralogical Magazine, 69: 937-949.

Tugarinov, A.I., Il'in, N.P., and Mokhanti, R., 1975. Fractionation of $\mathrm{Mn}$ and $\mathrm{V}$ between coexisting titanomagnetite and ilmenite and its significance in geothermometry. Geochemistry International, 11: 706-717.

\section{About the first author}

Dr Raju V.S. PERUMALA obtained his masters degree in Geology and M.Tech degree in Mineral Exploration from Osmania University, India. He is working as a Principal Scientist in CSIR-NGRI lab and a fellow of SEG \& FGS (Lon). He published $\sim 40$ SCI papers and presented $\sim 45$ papers in national and International conferences. Dr Raju specialized in Chromitite-PGE and associated mineralogical aspects. At present, he is carrying scientific investigations on Rare metals (RM) and Rare Earth Elements (REE). 